\title{
ІНТЕГРАЛЬНИЙ ПОКАЗНИК ОЦІНКИ СМЕРТНОСТІ ДЛЯ МОНІТОРИНГУ МЕДИЧНОГО ЗАБЕЗПЕЧЕННЯ РЕГІОНІВ УКРАЇНИ
}

\author{
Н. С. Рогозинська, Л. М. Козак \\ Міжнародний науково-навчальний центр інформаційних технологій та систем НАН і МОН \\ України
}

Medical statistic measure "summary disease-caused death rate" is given for use in monitoring and comprehensive analysis of healthcare in different regions of Ukraine.

3 реформуванням системи охорони здоров'я в Україні виникають нові можливості щодо оцінювання їі ефективності та планування змін в організації надання медичної допомоги і разом із тим - нові задачі: формування та обгрунтування комплексу показників для моніторингу стану здоров'я населення. На сьогодні для дослідження здоров'я населення здебільшого застосовують показники захворюваності та смертності.

Для кращого відображення взаємозв'язку захворюваності, поширеності та смертності внаслідок основних захворювань (тих, які є найбільш поширеними і основними причинами смертності населення України) пропонується до переліку вживаних індикаторів якості медичної допомоги додати комплексні індикатори оцінки смертності. Для порівняння загального стану забезпечення охорони здоров'я в різних адміністративно-територіальних одиницях України доцільно застосувати інтегральний показник оцінки смертності.

Мета роботи: визначити інтегральний показник оцінки смертності внаслідок найбілыш поширених захворювань та хвороб - основних причин смертності, для дослідження загального стану здоров'я населення різних регіонів.

Постановка задачі. Запропоновані нами комплексні індикатори складаються зі стандартних показників медичної статистики (на 100 тис. населення) і розраховуються за виразом:

$$
\text { EDdis }=\frac{\text { DRdis }}{D I S} \cdot \text { DISnew }
$$

де EDdis - комплексний індикатор «оцінка смертності внаслідок захворювання», який характеризує ризик причинної смертності з урахуванням даного рівня захворюваності; DRdis - смертність внаслідок захворювання; DIS - поширеність захворювання; DISnew - захворюваність на дану хворобу.

Хворобами, які є основними причинами смертності та найбільш поширені на території України, згідно 3 даними основних статистичних оглядів, $€$ : (1) хвороби системи кровообігу; (2) хвороби органів дихання; (3) цукровий діабет; (4) всі форми активного туберкульозу; (5) злоякісні новоутворення; (6) хвороби се() Н. С. Рогозинська, Л. М. Козак чостатевої системи; (7) хвороби нервової системи і (8) хвороби органів травлення.

Запропоновані комплексні індикатори можуть бути основою критеріїв оцінки приприйнятті рішеньщодо управління в охороні здоров'я. Оскільки індикатори є однаковими за розмірністю та незалежними за вибором, їх можна об'єднати в інтегральний показник «оцінка смертності внаслідокзахворюваності на основні хвороби».

Матеріали і методи. У дослідженні застосовано офіційні дані медичної статистики МОЗ України. До однорідних вибірок за 2004-2011 рр. увійшли дані щодо захворюваності, поширеності і смертності внаслідок захворювань (випадків на 100 тис. населення) у 26 адміністративно-територіальних одиницях: 24 областях, АР Крим і в Україні в цілому.

У роботі використано «метод площин», який застосовується для розрахунку інтегральних показників при дослідженнях у різних галузях $[1,2]$. Оцінки смертності внаслідок захворювань нормовано відносно мінімального значення в кожному окремому році та надано у вигляді пелюсткової діаграми для кожноїз досліджуваних адміністративно-територіальних одиниць.

Результати. Для кожної з досліджуваних адміністративно-територіальних одиниць розраховано значення комплексних оцінок смертності за роками досліджуваного періоду. Після цього індикатори нормовано і представлено у вигляді пелюсткової діаграми (рис. 1).

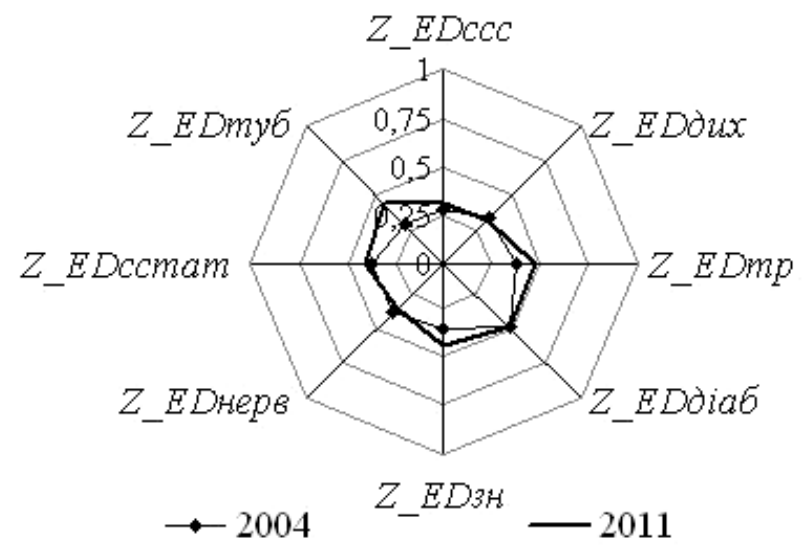

Puc. 1. Комплексні оцінки смертності внаслідок захворювань (по Україні в цілому). 
Значення інтегральних оцінок розраховано як площі областей, обмежених пелюстковими діаграмами, для кожного року і кожної адміністративно-територіаль- ної одиниці окремо. Площі областей розраховано як суму площ трикутників, 3 яких складається 8-кутНик:

$$
\begin{aligned}
& S=0,5 \cdot \sin \left(45^{\circ}\right) \cdot\left(Z_{-} E D c c c \cdot Z_{-} E D \partial u x+Z_{-} E D \partial u x \cdot Z_{-} E D m p+Z_{-} E D m p \cdot Z_{-}\right. \text {EDдіаб+ } \\
& +Z_{-} \text {ЕDдіаб } \cdot Z_{-} \text {ЕDзн }++Z_{-} \text {ЕDзн } \cdot Z_{-} \text {ЕDнерв }+Z_{-} \text {ЕDнерв } \cdot Z_{-} \text {EDсстат }+ \\
& \left.+Z_{-} E D c c m a m \cdot Z_{-} E D m y \sigma+Z_{-} E D m y \sigma \cdot Z_{-} E D c c c\right)
\end{aligned}
$$

Теоретично можливе максимальне значення інтегральної оцінки смертності становить 2,8. Максимальні значення за регіонами України $\left(\mathrm{S}_{\max }\right)$ склали 0,7-1,2 впродовж 2004-2011 pp. Інтегральна оцінка смертності внаслідок основних захворювань по Ук- раїні в цілому підвищувалась впродовж досліджуваного періоду і становила від 0,4 у 2004 р. до 0,5 - у 2011 p. На рисунку 2 представлено розподіл інтегральних оцінок смертності за областями України та АР Крим.

Puc. 2. Розподіл інтегральної оцінки смертності внаслідок найбільш поширених захворювань та хвороб основних причин смертності за адміністративнотериторіальними одиницями України.

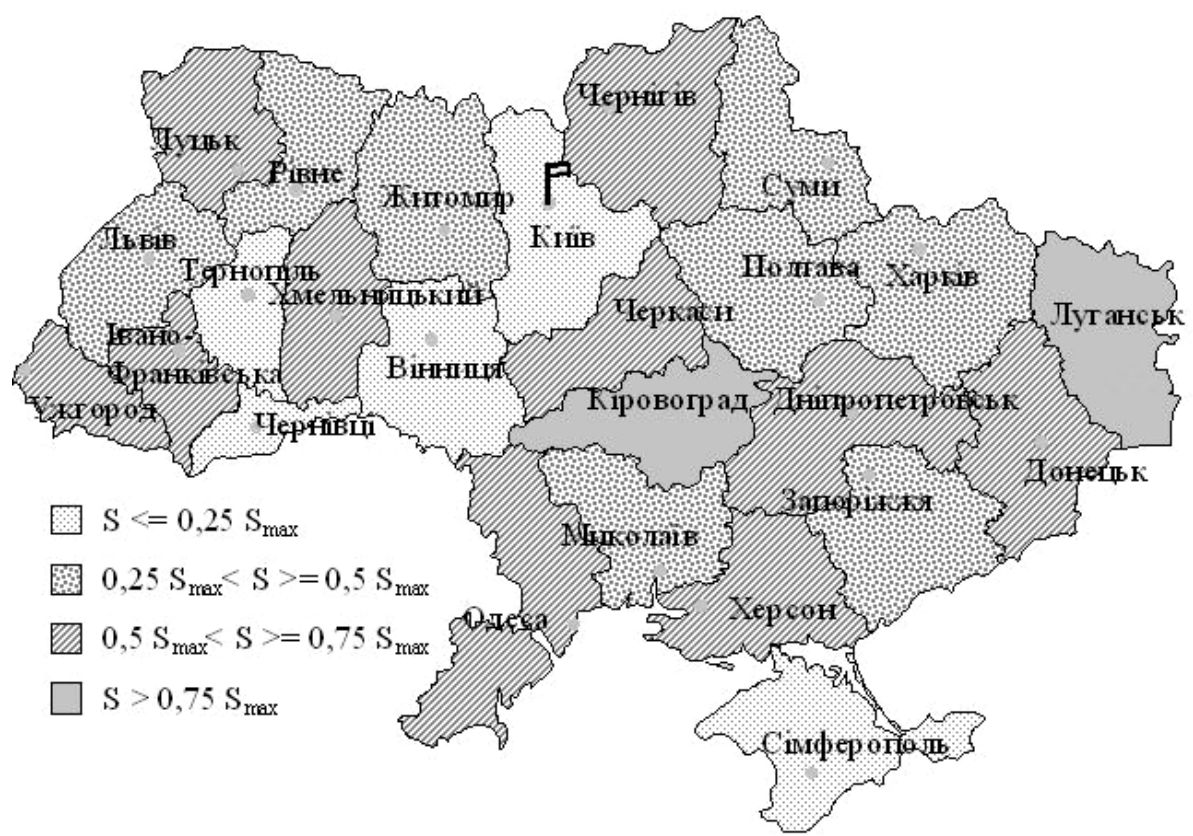

Висновки. Запропонований інтегральний показник оцінки смертності внаслідок основних захворювань базується на комплексних індикаторах оцінки смертності, які включають основні показники медичної статистики.

Залучення запропонованого інтегрального показника до системи моніторингу стану населення України не передбачає додаткових витрат. Застосу-

вання його для аналізу загального стану здоров'я населення в різних регіонах дозволяє виділити адміністративно-територіальні одиниці, в яких медичне забезпечення потребує організаційних втручань, а також проводити загальний аналіз динаміки стану здоров'я населення різних регіонів для дослідження впливу на нього заходів з реформування системи охорони здоров’я.

\section{Література}

1. Русакова Л. Т. Использование информационных технологий для анализа территориальных различий по показателю смертности / Л. Т. Русакова, М.Ю.Антомонов // Гігієна населених місць : зб. наук. пр. - Вип. 46. - Київ, 2005. C. 493-498.

2. Фасхиев X. А Оценка уровня конкурентоспособности грузовых автомобилей и их двигателей / Х. А. Фасхиев, А. В. Крахмалева // Маркетинг в России и за рубежом. 2004. - № 5. - C. 3-16. 